\title{
Curbing Digital Distractions in the Classroom
}

\author{
Corey Seemiller \& Sheri Stover \\ Wright State University, United States
}

\begin{abstract}
Whether banking, communicating, watching television, or shopping, people can now do nearly anything on their personal digital devices. This digital access even extends to the college classroom where students use their personal devices for a multitude of non-class related purposes. Findings from a survey of 193 college undergraduates found that during class, students access particular types of platforms more frequently than others, providing insight into what they are doing when they are on their devices. Overall, students more often engage in accessing class information, utilizing online communication, using online photo sharing, and information seeking than other platforms. Based on the findings of the study, recommendations for educators are offered.
\end{abstract}

Keywords: Technology; Classroom; Digital distraction; Learning

\section{Introduction}

There are many benefits for using technology in the classroom (see Campbell, 2006; D'Angelo \& Woosley, 2007). Access to learning apps, platforms, and nearly infinite amounts of information can provide for engaging instruction and meaningful student learning. However, not all technology use in class is beneficial. When used for non-course related purposes, students' technology use on their personal devices during class can pose a distraction to themselves and their peers.

Smartphones make it easier than ever to be and stay connected. Thirty-one percent of people who own a cell phone never turn it off, and $45 \%$ rarely do (Rainie \& Zickuhr, 2015). As beneficial as being connected can be, it can also be problematic. Rainie and Zickuhr (2015) point out, "This 'always-on' reality has disrupted long-standing social norms about when it is appropriate for people to shift their attention away from their in-person conversations and interactions with others towards digital encounters with people and information that are enabled by their mobile phone" (para. 6). Although Americans generally view cell phones as distracting and annoying when used in social settings, they still choose to use their devices when in these very settings evidenced by $89 \%$ who had reported doing so at the most recent social gathering they attended (Rainie \& Zickuhr, 2015). This constant connection is not solely limited to day-to-day life; it permeates college classrooms creating an environment where students toggle back and forth between their real and virtual experiences during a class session.

It is common to see people using their personal digital devices in places like stores, parks, and on public transportation. So, why is it less acceptable to use these devices during class? Campbell 
(2006) would argue that the college classroom is a unique place, both serving as a space for individual learning and community learning, which together contribute to a collectively focused social gathering. He adds that there is more at stake with an interruption of learning by a cell phone than when one might be out grocery shopping or riding the bus.

Given the use of their devices during class, students might not see classrooms any differently than other social spaces they occupy (Miller et al., 2011). McCoy (2013) found that undergraduate students used a digital device in the classroom for purposes unrelated to class more than 11 times a day. Tindell and Bohlander (2011) found that 30\% of students indicated sending or receiving a text message during class time every day; $54 \%$ also said that professors would be shocked if they knew how much texting was really going on during class.

This study aims to explore what specifically students are doing when they are using their personal devices during class as a way to offer strategies that address their specific personal device behavior.

\section{Literature Review}

Using digital technology for purposeful educational activities in the classroom has many benefits such as engagement with language, engagement in lecture, and increased connections to content (Piraino \& Wilson, 2015). However, when used for non-class related purposes, using devices can result in issues affecting the student user, peers, and the instructor that can result in inhibiting engagement and learning. Strategies for curbing these distractions may need to be nuanced depending on what students are doing on their devices as surfing the Internet might be more reflective of boredom, whereas digital communication might be more reflective of a need to stay connected to others.

\section{Issues of Digital Device Use for Non-class Related Purposes}

Two main issues arise when considering the implications of students using their devices during class. The first involves the issue of respect and courtesy. Students who are using their devices might have their attention drawn away from a group discussion or project, lose focus from the class causing their peers to miss out on peer learning, and further, have their phones ring, beep, buzz, or vibrate causing an audible distraction. Second, when students use their devices, they are pulled away from the learning environment into a virtual world. This can result in distracted and disconnected learning in which students mentally enter and exit the course content.

Lack of Courtesy. As many college students are preparing for professional roles after college, it is critical to understand personal digital device culture in the world of work. Robles (2012) found that courtesy, which includes being respectful, having manners, employing business etiquette, and being gracious, was more important to employers than interpersonal and teamwork skills, professionalism, work ethic, responsibility, and positive attitude. And the idea of courtesy in the workplace seems to include the notion of digital courtesy. In a study by Washington, Okoro, and Cardon (2013), more than three quarters of employees indicated believing it is rarely or never 
acceptable to check emails or texts or browsing the web during a formal meeting. Further, a 2014 Pew study found that only $5 \%$ of people think that it is okay to use a cell phone during a meeting (Rainie \& Zickuhr, 2015).

Smith (2012) reports that women are more likely to witness bad cell phone etiquette than men. That may be because more disrespectful phone use occurs in their presence or they have a stricter definition of what constitutes bad cell phone etiquette. The latter interpretation may be more consistent with what Washington et al. (2013) found in that during informal meetings, men are almost twice as accepting of checking and sending text messages and answering phone calls than women.

In regard to age, Washington et al. (2013) found that younger employees were more likely to view certain cell phone behaviors as appropriate during meetings compared to their older peers. During formal meetings, $51 \%$ of younger employees (21-30) believed that checking emails and texts during a formal meeting is acceptable; a number more than three times that of employees over 40 (Washington et al., 2013). This mentality of acceptability of cell phone use in the workplace also aligns with how younger individuals view cell phone use in social settings. For example, during a recent social gathering, $82 \%$ of 18 -29-year-olds had read a text message or email message, and $75 \%$ wrote one. Forty-nine percent browsed the Internet. These findings are starkly different from even the next highest user age bracket, the $30-49$-year-olds, where $72 \%$ had read an email or text, $65 \%$ had sent one, and 32\% had surfed the web (Rainie \& Zickuhr, 2015).

When it comes to college classrooms, having the ringer on a cell phone go off during class or watching a student try to text discreetly under the desk can appear disrespectful, both to the instructor as well as to the other students. In a study by Bjorklund and Rehling (2010), students rated various classroom behaviors on a civility scale with one being not uncivil and five being extremely uncivil, or those behaviors that impact the unity and wellbeing of the classroom community. They found that students considered text messaging during class and using a device for non-class related activities during class as somewhat uncivil.

In addition, McCoy (2013) found that when students were asked to report the top three disadvantages of using personal devices in class for non-class-related activities, $39 \%$ indicated distracting others, and $32 \%$ noted getting called out by the instructor, which can certainly be distracting to the class. Despite their recognition of these distracting behaviors, $33 \%$ indicated that they are not distracted when others use their devices during class. Like the workplace and social settings, age seems to be a factor in cell phone use acceptability in educational settings. Campbell (2006) found that youth are more tolerant than other age groups of the use of cell phones in the classroom.

Personal Distraction. Not only can using digital technology be perceived as disrespectful to others, but it can also be distracting to the individual using it. Foerde, Knowlton, and Poldrack (2006) found that when distracted, individuals have a harder time learning new things, and Sana, Weston, and Cepeda (2013) point out that when multi-tasking, attentional resources are depleted resulting in performance decreases. For example, Froese et al. (2012) found that students who engaged in active text conversations during a PowerPoint presentation leading up to a quiz had lower quiz scores by an average of $27 \%$ compared to students who were not texting during the presentation. 
Further, a study by Kuznekoff and Titsworth (2013) revealed that students who did not use their cell phones in class wrote down $62 \%$ more information, and their notes were more detailed. They could also recall more information presented in the lecture and earned on average a letter grade and a half higher on a test than the students who were actively engaged on their cell phones (Kuznekoff \& Titsworth, 2013).

The impact on learning is not solely limited to cell phone use. Duncan, Hoekstra, and Wilcox (2012) reported on an unpublished study by Diane Sieber, a professor from the University of Colorado, who found that students who were on their laptops frequently during class scored, on average, 11 percent lower in the course than students who were not using laptops. Although laptops offer a means for note taking, they can also provide an alluring opportunity for students to engage in the digital world rather than pay attention in class.

Students themselves know that using their personal devices during class splits their attention. McCoy (2013) found that $90 \%$ of students indicated not paying attention as one of the three biggest disadvantages to using a digital device in class for purposes not related to the class. In addition, $80 \%$ indicated missing instruction as another of the biggest disadvantages.

Given both issues of courtesy and self-distraction, Bayless, Clipson, and Wilson (2013) found that $47 \%$ of faculty members surveyed have a statement in their syllabus describing appropriate technology use in class, and $29 \%$ of those who did not have a statement indicated that having one could be useful.

\section{Why Students Use Personal Digital Devices during Class}

Knowing that using digital devices can be distracting to themselves and others, why would a student use a personal digital device in class? McCoy (2013) found that when students were asked to note the three biggest advantages to using their devices in class, those that emerged at the top of the list included staying connected, combatting boredom, reasons related to classwork, and for entertainment.

Staying Connected. McCoy (2013) found that $70 \%$ of students noted their need to stay connected as the most reported advantage of using digital devices in class. This desire for connection may be explained by a phenomenon called FOMO, or the Fear of Missing Out (Abel, Buff, \& Burr, 2016). FOMO is premised on the idea that a person is missing out on everything happening in a place other than where that person is. For example, while a student is in class, he or she could miss important conversations, relationship developments, and news. Powering down might mean powering out for an hour or two, which might result in feeling disconnected and disassociated. Abel, Buff, and Burr (2016) developed a scale to calculate an individual's FOMO score. They found that college students with high FOMO scores had a statistically significant higher urge to check social media during class. In addition, Rosen et al. (2013) found that not being able to check text messages, specifically, created the most anxiety of any device behavior.

Combatting Boredom. McCoy (2013) found that $55 \%$ of students believe the one of the top three advantages to using their devices during class is to combat boredom, and Ugar and Koc (2015) 
noted that $60 \%$ of students in their study report using their devices out of boredom. Flanigan and Babchuk (2015) also found that fighting boredom was a major determinant for students in using social media, specifically, during class. A student in their study reported, "(During) a really boring, un-interactive lecture where time is just going by slow, then I'll try and go on (social media) just to make time go by a little faster" (p. 43).

Reasons Related to Classwork. Although McCoy (2013) indicated that $49 \%$ of students in their study use their devices for reasons related to classwork, this study did not specify what this behavior might entail. Given the prominence of learning management systems, students may be downloading slides, accessing readings, or posting an assignment online. In addition, students may also be exploring course related concepts online to learn more as a lecture unfolds. Although these behaviors are related to classwork, they still may have the ability to distract students from what is happening during the class session.

Entertainment. Ugar and Koc (2015) further found that $13 \%$ of student use their devices just for fun. Checking messages or browsing the Internet may be more entertaining than what is happening in class. This may be especially true in the cases in which instructors simply lecture from the book or from slides that are posted online for students to view later. Not only might this not be engaging, students have no incentive to pay attention when they could be doing other, more interesting, things. This sentiment was echoed in Flanigan and Babchuk's (2015) study with a student sharing, "When I don't need to look at what they're saying because it's all in the book and their reading off the PowerPoints, I think I don't need to pay attention."

\section{What Students Do on Their Personal Digital Devices during Class}

Many students use personal digital devices during class, but what are they using them for? Aligning with the need to stay connected, McCoy (2013) found that texting, email, and social networking were among the top reasons. Web surfing and playing games also emerged, but lower on the list, reflecting the desire to engage in entertainment and fight boredom. In looking at gender differences, McCoy (2013) found that women were more likely than men to use their digital devices for social networking, whereas men were more likely to surf the web or play games. In addition, just with laptop use alone, Sample (2012) found that $35 \%$ of students indicated spending at least 10 minutes during class to check email and engage in social networking. And, Ugar and Koc (2015) in a study of 349 college students by found that $77.8 \%$ of students indicated using their phones to check the date or time, $56.9 \%$ to check texts, $41 \%$ to send texts, and nearly $32.9 \%$ to surf the web.

\section{Research Questions}

Much research appears to focus on why students use personal devices for unrelated course purposes or the impact of using these devices. However, there is less research about the platforms they are using and the frequency with which they use them. Uncovering this information may provide insight into specific strategies for curbing digital distraction. The purpose of this study is to gain a better understanding of the digital platforms unrelated to the course that students are 
using while in class. In addition, because of the differences found in the literature regarding personal device use with gender (see Smith, 2012; Washington et al., 2013) and age (see Rainie \& Zickuhr, 2015; Washington et al., 2013), this study includes research questions that disaggregate by these variables.

1. How frequently do students use various digital technology platforms unrelated to the course during class?

2. Is there a difference between traditional-aged students (18-21) and non-traditional-aged students older than 21 in the frequency of use of various digital technology platforms unrelated to the course during class?

3. Is there a difference between men and women in the frequency of use of various digital technology platforms unrelated to the course during class.

\section{Methodology}

The content analyzed for this article was drawn from a larger study involving deep learning and digital technology use. Before analyzing these larger constructs for intersectionality and relationships, it was important to first understand each construct separately. This article solely addresses the use of digital technology platform use in the classroom.

\section{Instrument}

There were 96 measurements in total on the instrument, with 17 being about digital technology platform use in the classroom. The prompt for these 17 measurements asked, "While you are in class, how often do you engage in the following activities unrelated to the class session? Students were asked to determine the frequency with which they used the following types of digital platforms in class (1) Never, (2) Very rarely, (3) Rarely, (4) Sometimes, (5) Frequently, and (6) Very frequently. In addition, demographic data on age and gender from the instrument were used in the analysis of these measurements.

Table 1. Types of Digital Platforms Survey Choices

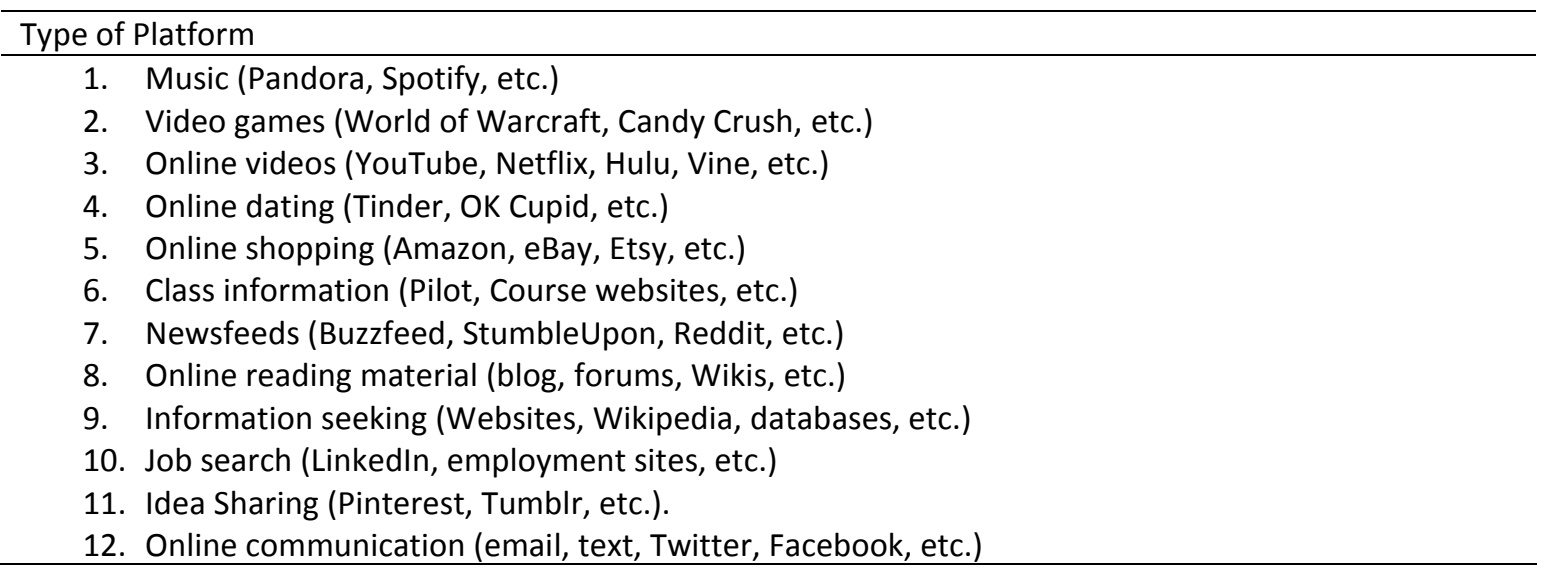


13. Online photo sharing (Snapchat, Instagram, Flickr, etc.)

14. Audio communication (phone, Skype, FaceTime, etc.)

15. Online Collaboration (Google Docs, Dropbox, File sharing, etc.)

16. Social Commentary (Yik Yak, Whisper, etc.)

17. Review Postings (RateMyProfessor, Yelp, Trip Advisor, etc.)

Notes. For each type of platform, students were asked to select one of the following responses: (1) Never, (2) Very rarely, (3) Rarely, (4) Sometimes, (5) Frequently, and (6) Very Frequently

\section{Data Collection}

To gather the data for this study, the authors worked with faculty members in an academic program focused on organizational leadership in a mid-size regional public university to administer the comprehensive instrument on deep learning and digital technology use during the first week of classes. The instrument a pre-printed scantron form, was administered in 19 classes in a Bachelor's level organizational leadership program. Classes were comprised of approximately 1535 students each and were taught face-to-face. The total enrollment number for all classes combined was 429 , although many students were taking more than one course and were asked to fill out the instrument only once. Because this study was anonymous, verification that the student did not complete the survey more than once was based on each student's verbal confirmation. Each faculty member collected all completed instruments and returned them in a sealed envelope to the authors of this study. Each completed instrument was scanned at the technology office on campus and data were sent to one of the authors in the form of a spreadsheet to use for analysis. This resulted in 233 students filling out the instrument, with 193, more specifically, completing all of the measurements related to digital technology use in the classroom as well as age, gender, and ownership of a smartphone. The gender breakdown was nearly even with 102 men and 91 women. In addition, 55 students were between the ages of 18 and 21, whereas 138 were over the age of 21 . Regarding the device ownership, 188 of the 193 responded to the question about whether or not they had a smartphone. One hundred eighty five indicated having one; all three who did not were over the age of 21 (two of those were over the age of 50).

\section{Data Analysis}

The purpose of this study was to build upon previous research around the use of digital platforms for non-course related purposes during class. Because the instrument included 79 measurements unrelated to the purpose of this study, only the 17 measurements about types of platform use were included in the analysis. To address research question 1 , the authors ranked platforms by the highest percentage of students who frequently ( 5 on the scale of 1-6) or very frequently ( 6 on the scale of 1-6) use the platform during class. Calculating percentages in this manner provided a way to ascertain to what extent students, in the aggregate, frequently or very frequently use variety of digital platforms, uncovering what the highest number of them do most often. In addition, the authors calculated the means for use (1-6 on the scale) to account for all levels of frequency usage (beyond frequently and very frequently). They used a Tukey HD test for means above 2.5 to uncover any statistical differences the most used platforms. 
The data were then disaggregated to two groups, 18-21 year-olds (traditional-aged students) and those older than 21 (non-traditional-aged students). The authors calculated the means for the frequency of use for each group for each type of platform and conducted t-tests to test for statistical significance between those means. A similar process was used when analyzing based on gender. Instead of age groups, self-reported gender categories of men and women were used to conduct the same type of analysis.

The focus for the analysis based on age and gender was solely on the difference between the means of the two groups and did not include a comparison of percentages of frequent/very frequent use. This was done to ensure that all students for both groups and not just frequent users were included in the analysis.

\section{Results}

\section{Frequency of Digital Technology Platform Use}

There appears to be a variation in the percentage of students who use each platform type frequently (5) or very frequently (6). The platforms that yielded the highest percentage of frequent use were those related to accessing class information (47\%), engaging in online communication (35\%), sharing photos online (24\%), and seeking information from websites (20\%). The lowest percentage were those related to accessing job search sites (7\%) and reviewing sites (7\%), playing video games (6\%), as well as accessing social commentary sites (4\%) and online dating sites (2\%).

In addition to analyzing for frequency, a mean was calculated for each platform to account for the variation in scores beyond those of frequently (5) and very frequently (6). The four highest and four lowest means were the same as the four highest and four lowest frequency percentages. See Table 2 for frequency percentage and mean for each type of platform.

Table 2. Platform Use

\begin{tabular}{|c|c|c|c|}
\hline Type of Platform & $\begin{array}{l}\text { \% Frequently/ } \\
\text { Very Frequently }\end{array}$ & $\begin{array}{c}M \\
(n=193)\end{array}$ & $S D$ \\
\hline Class Info & $47.15 \%$ & 4.04 & 1.54 \\
\hline Online Communication & $34.72 \%$ & 3.68 & 1.67 \\
\hline Online Photo Sharing & $23.83 \%$ & 2.98 & 1.83 \\
\hline Info Seeking & $20.21 \%$ & 2.96 & 1.65 \\
\hline Music & $19.69 \%$ & 2.25 & 1.86 \\
\hline Online Collaboration & $14.51 \%$ & 2.57 & 1.66 \\
\hline Online Videos & $13.47 \%$ & 1.96 & 1.58 \\
\hline Audio Communication & $12.44 \%$ & 1.99 & 1.64 \\
\hline Idea Sharing & $10.88 \%$ & 2.07 & 1.53 \\
\hline Online Shopping & $10.36 \%$ & 2.17 & 1.48 \\
\hline Online Reading & $9.33 \%$ & 2.11 & 1.46 \\
\hline Newsfeeds & $8.29 \%$ & 2 & 1.45 \\
\hline Job Search & $6.74 \%$ & 1.81 & 1.36 \\
\hline
\end{tabular}




\begin{tabular}{lccc} 
Reviews & $6.74 \%$ & 1.75 & 1.32 \\
Video Games & $5.70 \%$ & 1.6 & 1.22 \\
Social Commentary & $4.15 \%$ & 1.42 & 1.08 \\
Online Dating & $2.07 \%$ & 1.35 & 0.95 \\
\hline
\end{tabular}

Post hoc analyses were conducted given the statistically significant ANOVA F test. Specifically, Tukey HSD tests were conducted on all possible pairwise contrasts for any group with a mean of 2.5 or higher. The following pairs of groups were found to be significantly different $(p<.05)$ : Class Information $(M=4.04, S D=1.54)$ with Online Photo Sharing $(M=2.98, S D=1.83)$, Info Seeking $(M=2.96, S D=1.65)$, and Online Collaboration $(M=2.57, S D=1.66)$; Online Communication $(M=3.68$, $S D=1.67)$ with Online Photo Sharing $(M=2.98, S D=1.83)$, Info Seeking $(M=2.96, S D=1.65)$, and Online Collaboration $(M=2.57, S D=1.66)$. These results signify that both accessing class information and online communication appear to be the platforms of choice for students to use during class.

\section{Differences by Age}

Because age plays a role in the perceptions and use of technology on personal devices (Washington et al., 2013; Rainie \& Zickuhr, 2015; Campbell, 2006) and the importance of acknowledging the constant changing age demographic in higher education, the authors sought to understand any differentiation between two specific age groups. These included traditional-aged students (18-21-year-olds) and non-traditional aged students ( 22 and older). Table 3 highlights the mean score and results of t-tests between both groups for each platform type. Overall, other than seeking information online, the means for traditional-aged students were higher across every type of platform. However, only two types of platforms yielded a statistically significant difference between the two groups. There was a significant effect for online photo sharing, $t(191)=2.4, p<.05$, with traditional-aged students having a higher mean than non-traditional aged students. This was also true for social commentary, $t(191)=2.84, p<.01$, with traditional-aged students having a higher mean than non-traditional aged students.

Table 3. Platform Use by Age

\begin{tabular}{lcccccc}
\hline \multicolumn{1}{c}{ Platform } & \multicolumn{2}{c}{ Traditional } & \multicolumn{2}{c}{ Non Traditional } & & \\
\hline Class Info & $M$ & $S D$ & $M$ & $S D$ & $P$ & $t .64$ \\
Online Communication & 4.33 & 1.5 & 3.93 & 1.54 & 0.1 & 0.35 \\
Online Photo Sharing & 3.75 & 1.68 & 3.65 & 1.67 & 0.73 & 2.4 \\
Info Seeking & 3.47 & 1.71 & 2.78 & 1.84 & $0.017^{*}$ & 0.55 \\
Online Collaboration & 2.85 & 1.61 & 3 & 1.67 & 0.58 & 1.03 \\
Music & 2.76 & 1.61 & 2.49 & 1.68 & 0.31 & 0.69 \\
Online Shopping & 2.4 & 2 & 2.2 & 1.8 & 0.49 & 1.06 \\
Idea Sharing & 2.35 & 1.61 & 2.09 & 1.42 & 0.29 & 1.47 \\
Online Reading & 2.33 & 1.69 & 1.97 & 1.45 & 0.14 & 0.08 \\
Audio Communication & 2.13 & 1.4 & 2.11 & 1.48 & 0.94 & 0.74 \\
Online Videos & 2.13 & 1.67 & 1.93 & 1.63 & 0.46 & 0.63 \\
Newsfeeds & 2.07 & 1.68 & 1.91 & 1.54 & 0.53 & 0.11
\end{tabular}




\begin{tabular}{lcccccc} 
Job Search & 1.87 & 1.35 & 1.79 & 1.37 & 0.7 & 0.38 \\
Reviews & 1.82 & 1.35 & 1.72 & 1.31 & 0.66 & 0.44 \\
Social Commentary & 1.76 & 1.36 & 1.28 & 0.92 & $0.005^{*}$ & 2.84 \\
Video Games & 1.71 & 1.21 & 1.56 & 1.23 & 0.44 & 0.78 \\
Online Dating & 1.4 & 1.06 & 1.33 & 0.9 & 0.66 & 0.44 \\
\hline
\end{tabular}

Notes. Gen Z ( $n=55)$; Other Gen $(n=138) * \mathrm{p}<.05$

\section{Differences by Gender}

Both Smith (2012) and Washington et al. (2013) found that gender is related to perceptions of appropriate cell phone usage. Although most college classrooms are not divided by gender, disaggregating by gender can help uncover any nuances in platform use that may not emerge when only looking at aggregate data so as to ensure strategies to curb digital distractions include behavior that may be specific to gender. Given that, the authors sought to understand if there is a difference in the frequency of use of each platform between those who identified as men and those who identified as women. Table 4 highlights the means and t-test results for each platform. The means for 13 of the 17 platforms yielded no statistically significant difference based on gender. However, women had statistically significant higher means for looking up class information, $t(191)=2.01, p<.05$, sharing ideas on the Internet, $t(191)=3.20, p<.01$, and online shopping, $t(191)=4.49, p<.01$. And, men had a higher mean for playing video games, $t(191)=3.20$, $\mathrm{p}<.01$.

Table 4. Platform Use by Gender

\begin{tabular}{|c|c|c|c|c|c|c|}
\hline \multirow[b]{2}{*}{ Platform } & \multicolumn{2}{|c|}{ Men } & \multicolumn{2}{|c|}{ Women } & \multirow[b]{2}{*}{$p$} & \multirow[b]{2}{*}{$t$} \\
\hline & $M$ & $S D$ & $M$ & $S D$ & & \\
\hline Class Info & 3.83 & 1.59 & 4.27 & 1.45 & $0.05^{*}$ & 2.01 \\
\hline $\begin{array}{l}\text { Online } \\
\text { Communication }\end{array}$ & 3.55 & 1.69 & 3.82 & 1.64 & 0.25 & 1.14 \\
\hline Info Seeking & 3.01 & 1.71 & 2.9 & 1.59 & 0.65 & 0.46 \\
\hline $\begin{array}{l}\text { Online Photo } \\
\text { Sharing }\end{array}$ & 2.93 & 1.85 & 3.03 & 1.82 & 0.7 & 0.38 \\
\hline $\begin{array}{l}\text { Online } \\
\text { Collaboration }\end{array}$ & 2.43 & 1.58 & 2.73 & 1.73 & 0.22 & 1.23 \\
\hline Music & 2.41 & 1.83 & 2.08 & 1.88 & 0.21 & 1.25 \\
\hline Online Reading & 2.22 & 1.51 & 2 & 1.39 & 0.31 & 1.03 \\
\hline Online Videos & 2.15 & 1.67 & 1.75 & 1.45 & 0.08 & 1.77 \\
\hline Newsfeeds & 2.07 & 1.52 & 1.92 & 1.38 & 0.49 & 0.69 \\
\hline Audio Com & 1.99 & 1.61 & 1.99 & 1.68 & 1 & 0.01 \\
\hline Video Games & 1.86 & 1.42 & 1.31 & 0.87 & $0.002^{*}$ & 3.20 \\
\hline Idea Sharing & 1.75 & 1.32 & 2.44 & 1.67 & $0.002 *$ & 3.20 \\
\hline Reviews & 1.75 & 1.37 & 1.75 & 1.26 & 0.97 & 0.04 \\
\hline Online Shopping & 1.74 & 1.18 & 2.65 & 1.64 & $0.0001^{*}$ & 4.49 \\
\hline Job Search & 1.7 & 1.31 & 1.95 & 1.42 & 0.21 & 1.27 \\
\hline
\end{tabular}




\begin{tabular}{lllllll} 
Social & 1.46 & 1.19 & 1.37 & 0.95 & 0.58 & 0.56 \\
Commentary & 1.36 & 0.95 & 1.34 & 0.95 & 0.87 & 0.16 \\
Online Dating & 1.36 \\
\hline
\end{tabular}

Notes. Men $(n=102) ;$ Women $(n=91) * p<.05 ; d f=191$

\section{Discussion}

It is no question whether or not students are on their devices during class. Both research and simple observation from anyone who has ever taught a course in college can assert that students have a hard time powering down their devices. We know that some students see this behavior as inappropriate and may curb their own use, whereas others might not recognize that being connected online can result in being disconnected and distracted in class. Regardless of their selfawareness of the impact of using their devices during class, students are still choosing to use them. The results of this study indicate what they are doing when they are on their devices.

\section{Accessing Class Information}

This study revealed that the platform used frequently or very frequently by the highest percentage of students was accessing class information during class. Although this may be distracting to others as well as can impede their ability to pay attention, is it more acceptable for students to get on their devices to look up information that might not be related to the immediate content of that class session but is at least related to the course in general? Examples of this may include looking at an upcoming assignment on the learning management platform to generate questions to ask the instructor before class is over or opening slides posted from a previous session to help them clarify what they are learning in that moment. However, not all behavior on course websites might be this innocuous. For example, students who are on course platforms typing up a late discussion post or taking a quiz for another class may be just as distracting and distracted as if they were playing a game or typing a blog. More research in distinguishing the depth of their engagement while accessing class information as well as what specifically they are doing when accessing class information could provide insightful in determining how distracted or disconnected they are from what is currently occurring in the class session.

\section{Online Communication}

Perhaps a more concerning behavior than the frequent accessing of class information is the amount of online communication occurring during class. Whether students are on social media, texting, or emailing, this behavior is often not related to the class session. When students check their messages, even if they do not respond to them, they run the risk of getting bad news or an inappropriate message that sits unanswered for the duration of the class time only creating a preoccupation with responding or eliciting emotions that can distract from learning. And, for those who do respond to messages, they may end be in several virtual conversations at one time during class. For example, a student could be chatting with a friend about a recent breakup while 
maintaining a conversation with a parent about an upcoming visit while discussing with a significant other an important relationship issue. Not only can the student be pulled away from the course content in one direction, the multiplicity of possible conversations may pull that student in several different directions. As some students may simply be responding to a quick text message, others may be highly distracted by an ongoing digital conversation, indicating the importance of future research in regard to the depth or longevity of the communication.

\section{Online Photo Sharing}

Initially surprising, the authors found that nearly one-quarter of students frequently or very frequently share photos online during class. A recent Pew Report found that $28 \%$ of all US adults use Instagram, a popular photo-sharing app, which is a higher number of users than Twitter, LinkedIn, or Pinterest (Greenwood, Perrin, \& Duggan, 2016). Further, 59\% of all 18-29-year-olds are Instagram users. These findings are consistent with results from a study by Seemiller and Grace (2016) who found that students who they refer to as Generation Z (today's 18-21 year-olds) share information on Instagram more than any other social media site. And, Instagram is not the only popular photo sharing app; Snapchat is now surpassing Twitter's user numbers (Frier, 2016). These apps make it easier and more alluring to post and view photos. Students can send selfies, photos with filters applied, and even captioned thoughts through their images. Communicating through imagery seems to be popular today, so perhaps photo sharing is the modern day messaging. But, what photos are they sharing? Are they posting pictures they are taking in class? Or are these pictures ones they have taken before class? The pictures might also simply be photos they received from others that they are re-posting. Given that this study found that online photo sharing was statistically significantly higher for younger students, faculty members may need to be aware this could be a growing behavior as more from this younger generation fill classrooms in the future.

\section{Information Seeking}

Just more than $20 \%$ indicated seeking information from websites. This behavior may entail just looking up small pieces of information like what time a place of business is open to make plans to stop by on the way home from class or tracking a package that was supposed to have been delivered already. These actions could simply be quick interruptions to get a piece of information that is necessary to alleviate a question or concern on their minds before re-engaging fully in the class. For example, a student who is waiting for a prescription authorization from a doctor might check their device during class to see the status. Learning that the authorization was granted might reduce any stress or concern about this issue that student had when coming to class. In some sense, this might help the student focus more on their learning for the duration of class even though that person checked out for a minute. On the other hand, this behavior has risks. If a student finds that the news is not good or is unexpected (like the authorization was denied), the student may then become pre-occupied thinking about this matter throughout class, impacting their focus and ultimately their learning. 
Beyond simply looking up answers to small questions, students may also seek out information online to do something else to combat real or perceived boredom. For example, they may look up a favorite athlete's stats or movie summaries. This type of behavior may be less about trying to find a quick answer but more reflective of simply surfing the web. However, what may start as a simple web search may result in the creation of an alternative learning space where students become so immersed in another topic online that they lose total connection with the course content happening in their own real space. This deep dive into the digital world can be distracting and disengaging for the student.

\section{Platforms with Less Frequent Use}

Although this study found frequency of use to be moderate, some students are listening to music, collaborating online, watching videos, talking on the phone or video chatting, sharing ideas online (women more than men), shopping online (women more than men), and reading blogs or news feeds during class. But, overall most students are not actively job searching, reading reviews, playing video games (men more than women), accessing social commentary sites (traditional-aged students more than non-traditional aged students), and getting on online dating sites during class.

\section{Recommendations}

What emerged from this study is that students do not appear to be engaging as much in timeconsuming and immersive online experiences like job searching, playing video games, reading, shopping, searching dating sites, writing blogs or commentaries, or watching videos during class; their behavior is mostly centered around shorter bursts of seeking or exchanging information. The following recommendations are offered based on the four most prominent activities students reported using their personal digital devices for during class. These include accessing class information, online communication, online photo sharing, and information seeking. The first set of recommendations offer ideas that address all four activities, followed by relatively specific recommendations based on each specific activity.

\section{Curbing Digital Distractions}

- A common way to address digital distractions, regardless of what students are doing on their devices, is to simply have a no-devices policy (Cheong, Shuter, \& Suwinyattichaiporn, 2013). Whether having a no cell phone policy or a laptop-free zone, Ugar \& Koc (2015) emphasize the importance of enforcing whatever policy is in place.

- Share your rationale for why you have a personal digital device policy in place, so students have a better understanding of how the policy fits into the goals and culture of the course (Cheong, Shuter, \& Suwinyattichaiporn, 2013).

- Have the class share a time when they witnessed inappropriate use of personal devices. Further, have them reflect on a time that they experienced someone disconnected, distracted, or inappropriately using their device in their presence and how that experience made them feel. Tie their personal experiences into creating a welcoming, engaged, and courteous 
classroom community. Then, have students create their own classroom norms around the use of personal devices and then hold them accountable to their own standards (Miller et al., 2011).

- Be mindful about not lecturing right out of the book or from slides that students later have access to, which can reduce the need for them to stay engaged during class (Flanigan \& Babchuk, 2015). Incorporating original and unique content into the course can provide an incentive for engagement and participation.

- Let students know that research has shown that being distracted by personal devices like phones, laptops, or tablets, may make it more difficult to earn a higher grade (Kuznekoff \& Titsworth, 2013; Froese et al., 2012; Duncan, Hoekstra, \& Wilcox, 2012). Let them know that you will be asking an application question at the end of class that requires them to apply a concept from that day's lesson to a real life scenario. Share with them that those students who were less distracted and more engaged will likely be able to answer the question more effectively and thus earn a better grade.

\section{Curbing Digital Distractions around Accessing Class Information}

- To help curb students using the learning management system during class (unless that is a critical part of the class), consider locking content during class and opening it afterwards. This may be especially useful for discussion boards and other assignment portals that students may be using during class to work on assignments that were due that day.

\section{Curbing Digital Distractions around Online Communication}

- Have students practice disconnecting from their devices while at home perhaps reducing their need to be hyperconnected during class.

- Have 1-minute tech breaks every 30 minutes of class time for students to check their messages. Each week extend the length of time between breaks by 5 minutes (Kamanetz, 2015).

- Have students turn off their devices and put them out of sight. Cheever, Rosen, Carrier, and Chavez (2014) found that students who are moderate device users experienced a steady increase in anxiety only when the device was out of their possession but not when it was nearby, but powered off. So, keeping their devices nearby, but in the off mode, might make students feel less anxious about needing to check their messages.

- For those who may have a fear of missing out by shutting off their devices, help address this concern by talking about it as a class. Listen to their concerns and ask for students who have managed a healthy balance in using their devices to share strategies that have worked for them.

\section{Curbing Digital Distractions around Online Photo Sharing}

- Incorporating technology into the classroom can offer an opportunity for student engagement (Miller et al., 2011). Given their interest in online photo sharing, consider integrating image and video creation and sharing into the curriculum so that students fulfill their desire to engage with their devices but are doing so with activities directly related to the class content. 
Photo sharing apps like Instagram and Snapchat or video creation sites like Powtoons or Jing offer innovative and engaging ways to incorporate image and video-based technology into the curriculum.

\section{Curbing Digital Distractions around Information Seeking}

- As students may be engrossed in surfing the web or looking up content online, it is important to engage in strategic redirection, which involves making comments to "help channel students' attention to their digital distractions back to instructors' teachings in class" (Cheong et al., 2013, p.278). Use language such as "Please put your phones in your bags for this next exercise."

- Use extemporaneous practices in having students search for information online using their devices (Cheong et al., 2013). For example, in the middle of presenting content, ask for students to search for examples online that reflect that content. Even asking a simple trivia question in which students get online, find the information, and respond using an online polling app like Kahoot.it to enter their response can capitalize on students' desire to search online for information.

- Engage students in active learning using applied, interactive, and stimulating activities so that they are immersed in the learning activities rather than being allured by their devices (Flanigan \& Babchuk, 2015).

An important consideration, not just with this study but also with all studies on this topic, is that personal devices can be critical learning tools for students with disabilities. It is imperative to make sure to not create policies or practices that single out students who need adaptive technology or holding them to policies requiring them to shut down devices, making learning unnecessarily difficult. Technology has come a long way and has helped many students engage in learning that without technology might be challenging or even impossible. The key is to provide an engaging environment for students to learn best, and for some, it means incorporating adaptive technology, and for others, it means having them disconnect from distracting behavior on their personal devices.

\section{Limitations}

This study offers a descriptive insight into students' use of digital technology during class for unrelated course purposes. Although the authors were able to uncover what types of platforms students use more frequently, this study did not explore why students use some platforms more than others or what they do specifically on these platforms. Because of the number of participants in this study, the authors only disaggregated users by age (only two groups) and gender. A study with more participants and more demographic disaggregation (such as race or socioeconomic status) could provide more insight into the nuances of platform use. Finally, this study was undertaken at only one institution with students in one major, making this not generalizable across higher education. Having a multi-institutional study with students of various majors might have provided both a larger sample as well as a diverse participant pool, allowing the authors greater opportunity for disaggregation and even comparisons between institutions. 


\section{Considerations}

It is also critical to consider the context within which this study took place. The students surveyed were in classes with low enrollment (no more than 35) making some digital behaviors appear more inappropriate than if they were in lecture halls of 500. They run the risk of being noticed or even more so, being called out by the instructor, when using their devices in these smaller classes.

In addition, the interactive nature of the classes in this organizational leadership program might make it difficult for students to use any platforms for a long duration, like reading, playing a game, or watching a video. Just when they would have started reading, playing, or watching something, they might be called to participate in a teambuilding activity or group discussion, thus interrupting their online disengagement time.

And the nature of the content may matter as well. The course content across the organizational leadership is more affective (e.g. emotional intelligence, leadership development, self-awareness) than cognitive (e.g. facts, theories, procedures). Affective content often involves using highly reflective and interactive pedagogies, perhaps making class time engaging enough not to have students' attention drawn away by their devices. Given that there are few tests or quizzes in this program, students may feel they have more opportunity to mentally check in and out of the course content because they will not be tested on it later.

\section{Conclusion}

Using technology in the classroom can offer many educational benefits (see D'Angelo \& Woosley, 2007; Campbell, 2006). Yet, this study highlighted that students appear to be frequently using their personal devices for activities other than enhancing their learning. Whether they are texting, sharing photos, or surfing the web, students' attempt at a simultaneous presence in both a real and virtual space can be both disrespectful to others (see Bjorklund \& Rehling, 2010; McCoy, 2013), as well as personally distracting (see Froese et al., 2012; Kuznekoff \& Titsworth, 2013). The challenge is to help students curb these disruptive activities not so much because they are required to, but because they understand the importance of doing so.

\section{References}

Abel, J. P., Buff, C. L., \& Burr, S. A. (2016). Social media and the fear of missing out: Scale development and assessment. Journal of Business \& Economics Research, 14(1), 33-44.

Bayless, M. L., Clipson, T. W., \& Wilson, S. A. (2013). Faculty perceptions and policies of students' use of personal technology in the classroom. Faculty Publications. Paper 32. Retrieved on 10 March 2017 from http://scholarworks.sfasu.edu/businesscom_facultypubs/32

Bjorklund, W. L \& Rehling, D. L. (2010). Student perceptions of classroom incivility. College Teaching, 58, 15-18. DOI: 10.1080/87567550903252801. 
Campbell, S. W. (2006). Perceptions of mobile phones in college classrooms: Ringing, cheating, and classroom policies. Communication Education 55(3), 280-294.

Cheever, N. A., Rosen, L. D., Carrier, L. M., \& Chavez, A. (2014). Out of sight is not out of mind: The impact of restricting wireless mobile device use on anxiety levels among low, moderate and high users. Computers in Human Behavior, 37(2014), 290-297.

Cheong, P. H., Shuter, R., \& Suwinyattichaiporn, T. (2013). Managing student digital distractions and hyperconnectivity: Communication strategies and challenges for professorial authority. Communication Education, 65(2), 272-289.

D'Angelo, J. M. \& Woosley, S. A. (2007). Technology in the classroom: Friend or foe. Education, $127(4), 462-471$.

Duncan, D. K., Hoekstra, A. R., \& Wilcox, B. R. (2012). Digital devices, distraction, and student performance: Does in-class cell phone use reduce learning? Astronomy Education Review, 11(1), 1-4.

Flanigan, A. E. \& Babchuk, W. A. (2015). Social media as academic quicksand: A phenomenological study of student experiences in and out of the classroom. Learning and Individual Differences, 44(2015), 40-45.

Foerde K., Knowlton B.J., Poldrack R.A. (2006). Modulation of competing memory systems by distraction. Proceedings of the National Academy of Sciences, 103, 11778-11783.

Frier, S. (2016). Snapchat passes Twitter in daily usage. Bloomberg Technology. Retrieved from https://www.bloomberg.com/news/articles/2016-06-02/snapchat-passes-twitter-in-dailyusage

Froese, A. D., \& Carpenter, C. N., \& Inman, D. A., Schooley, J. R., Barnes, R. B., Brecht, P. W., \& Chacon, J. D. (2012). Effects of classroom cell phone use on expected and actual learning. College Student Journal, 46(2), 323-332.

Greenwood, S., Perrin, A., \& Duggan, M. (2016). Facebook usage and engagement is on the rise, while adoption of other platforms holds steady. Pew Report. Retrieved on 10 March 2017 from http://www.pewinternet.org/2016/11/11/social-media-update-2016/

Kamanetz, A. (2015). How to get students to stop using their cellphones in class. Retrieved on 10 March 2017 from http://www.npr.org/sections/ed/2015/11/10/453986816/how-to-getstudents-to-stop-using-their-cellphones-in-class

Kuznekoff, J. H. \& Titsworth, S. (2013). The impact of mobile phone usage on student learning. Communication Education, 62(3), 233-252.

McCoy, B. (2013). Digital distractions in the classroom: Student classroom use of digital devices for non-class related purposes, Faculty Publications, College of Journalism \& Mass Communications. Paper 71. Retrieved on 10 March 2017 from http://digitalcommons. unl.edu/journalismfacpub/71

Miller, M., Berg, H., Cox, D., Carwile, D., Gerber, H., McGuire, M., ...Williams, J. (2011). A bird's eye view of an I-phone world: Differing perceptions of cell phone use in academic settings.

Eastern Education Journal, 40(1), 3-10. 
National Association of Colleges and Employers. (2016). Job outlook 2016: Attributes employers want to see on new college graduates' resumes. Retrieved on 10 March 2017 from http://www.naceweb.org/s11182015/employers-look-for-in-new-hires.aspx

Piraino, A. B. \& Wilson, L. B. (2015). An engaging distraction: Cell phones in the classroom. In Society for Information Technology \& Teacher Education International Conference (Vol. 2015, No. 1, pp. 2511-2516).

Rainie, L. \& Zickuhr, K. (2015). Americans' views on mobile etiquette. Pew Research Center: Internet, Science \& Tech Report. Retrieved on 10 March 2017 from http://www. pewinternet.org/2015/08/26/americans-views-on-mobile-etiquette/

Robles, M. M. (2012). Executive perceptions of the top 10 soft skills needed in today's workplace. Business Communication Quarterly, 75, 453-465.

Rosen, L. D., Whaling, K., Rab, S. A., Carrier, L. M., \& Cheever, N. A. (2013b). Is Facebook creating "iDisorders"? The link between clinical symptoms of psychiatric disorders and technology use, attitudes and anxiety. Computers in Human Behavior, 29(3), 1243-1254.

Sample, M. (2012, March 20). Best practices for laptops in the classroom. The Chronicle of Higher Education.

Sana, F., Weston, T., \& Cepeda, N. J. (2013). Laptop multitasking hinders classroom learning for both users and nearby peers. Computers \& Education, 62(2013), 24-31.

Seemiller, C. \& Grace, M. (2016). Generation Z goes to college. San Francisco, CA: Jossey-Bass.

Smith, A. (2012). The best (and worst) of mobile connectivity. Washington, DC: Pew Internet \& American Life Project.

Tindell, D. R. \& Bohlander, R. W. (2011). The use and abuse of cell phones and text messaging in the classroom: A survey of college students. College Teaching, 60(1), 1-9.

Ugar, N. G., \& Koc, T. (2015). Time for digital detox: Misuse of mobile technology and phubbing. Procedia - Social and Behavioral Sciences, 195(2015), 1022-1031.

Washington, M. C., Okoro, E. A., \& Cardon, P. W. (2013). Perceptions of civility for mobile phone use in formal and informal meetings. Business Communication Quarterly, 77(1), 52-64.

Correspondence: Corey Seemiller, Assistant Professor, Leadership Studies in Education and Organizations, Wright State University, Dayton, Ohio, United States. 